\title{
Prevalence of nutritional anemia in children of high socioeconomic status in a tertiary care center
}

\author{
Pradeep Kalaiselvam ${ }^{1}$, Suresh Chelliah ${ }^{2}$, Meganathan Pachamuthu ${ }^{3}$ \\ From ${ }^{1}$ Junior Resident, ${ }^{2}$ Chief Consultant Paediatrician, ${ }^{3}$ Consultant Paediatrician, Department of Paediatrics, Kauvery Hospital, Trichy, Tamil Nadu, India
}

\begin{abstract}
Background: Anemia is a highly prevalent condition developed in children belonging to all socioeconomic status and is mainly caused due to iron deficiency in nutrition. Aim: To identify the Prevalence of nutritional anemia in children of high socioeconomic status. Methods: Children between 6 months and 14 years of age belonging to high socioeconomic status, admitted in pediatric ward of Kauvery Hospital, a tertiary center at Trichy were included in the study. Children with hemolytic anemia, chronic illnesses, and those who received blood transfusion were excluded from the study. The World Health Organization classification was used for grading the severity of anemia as mild, moderate, and severe based on hemoglobin levels for the age. Modified Kuppuswamy scale 2016 was used to assess the socioeconomic status of the children. Children belonging to upper and upper middle socioeconomic status were included in the study. Results: The overall prevalence of anemia among the study population was $44.5 \%$. Out of 400 subjects, 178 participants were anemic. Of the 178 anemic children, $78.1 \%$ were in the age group of 6 months -5 years, $20.2 \%$ in 5-11 years, and 1.7\% in $12-14$ years. Among children between 6 and 23 months, 75 were anemic. Almost all patients showed microcytic hypochromic anemia. There were a significantly higher number of overweight and obese children among those anemic in all age groups. Conclusion: This study concludes that every other child is anemic even in families of high socioeconomic status, especially $<2$ years of age. There is an urgent need to screen and treat all children regardless of their socioeconomic status or body mass index.
\end{abstract}

Key words: Age group, High socioeconomic status, Nutritional anemia, Overweight

A nemia is a common public health problem affecting approximately one-third of world's population [1]. In 2011, approximately 300 million children had anemia throughout the world. A systematic analysis of global burden of anemia from 1990 to 2010 showed that the prevalence of anemia in children under 5 was still high [2-4]. According to National Family Health Survey (NFHS-4, 2015-2016), 58.5\% of children are anemic. About $50.4 \%$ of children between 6 and 59 months are anemic in Tamil Nadu; the prevalence of anemia in children $<2$ years of age is $70 \%[5,6]$. The World Health Organization (WHO) classifies the prevalence of anemia as severe when the percentage of anemic population is $>40 \%$, moderate between $20 \%$ and $39 \%$, and mild between $5 \%$ and $9 \%$ [7]. Approximately 2 billion people worldwide are iron deficient of which about 500 million have anemia [2].

Iron deficiency is the most common micronutrient deficiency in children and the most common cause for microcytic hypochromic anemia worldwide $[8,9]$. Anemia is considered to be a proxy

\section{Access this article online}

Received - 11 August 2021

Initial Review - 27 August 2021

Accepted - 15 September 2021

DOI: $10.32677 / \mathrm{IJCH} .2021 . v 08.110 .3060$ indicator of iron deficiency and is most commonly caused by low iron bioavailability and poor nutritional iron intake [9]. Children with normal nutritional status may also be iron deficient due to consumption of foods with low bioavailability of dietary iron, consumption of absorption inhibitors, and low consumption of foods that stimulate iron absorption. Maternal iron deficiency would also result in decreased iron reserves in the infant $[10,11]$. Other manifestations of iron deficiency include pica, increased risk for thrombosis, impaired psychomotor and mental development, functional abnormalities of lymphocytes, breath holding spells, decreased exercise performance, and restless leg syndrome [10]. Iron is necessary for function of various enzymes in neural tissues, and its deficiency causes neurocognitive deficits. Cognitive impairment of those children whose iron deficiency is not corrected before 2 years of age may be irreversible [11,12].

Iron deficiency is increasingly prevalent among the overweight and obese children, contrary to common belief. It is due to excess adiposity causing release of hepcidin which, in turn, decreases iron transport, thereby leading to deficiency [13,14].

Low socioeconomic status is considered to be a risk factor for nutritional anemia, particularly iron deficiency anemia. There

Correspondence to: Dr. Suresh Chelliah, Department of Paediatrics, Kauvery Hospital, Trichy, Tamil Nadu, India. E-mail: chelliah.suresh@yahoo.co.in

(C) 2021 Creative Commons Attribution-NonCommercial 4.0 International License (CC BY-NC-ND 4.0). 
are various studies on prevalence of anemia in children of low socioeconomic status and in children belonging to rural areas, but limited data are available for anemia in children belonging to high socioeconomic status. The present study was undertaken to estimate the prevalence of anemia in children of high socioeconomic status getting admitted in our hospital.

\section{METHODS}

Children between 6 months and 14 years of age belonging to high socioeconomic status, admitted to the pediatric ward of Kauvery Hospital, a tertiary center at Trichy were included in the study conducted from January 2017 to March 2018. Children with hemolytic anemia, chronic illnesses, and those who received blood transfusion were excluded from the study.

Detailed history, clinical examination, and hematological profile was collected from the study population. The WHO classification was used for grading the severity of anemia as mild, moderate, and severe based on hemoglobin levels for the age. Hematological parameters considered were hemoglobin, hematocrit, platelets, mean corpuscular volume, mean corpuscular hemoglobin, mean cell hemoglobin concentration, red cell distribution width, and peripheral smear. Modified Kuppuswamy scale 2016 was used to assess the socioeconomic status of the children [15]. Children belonging to upper and upper middle socioeconomic status were included in the study.

Descriptive statistics were reported in mean \pm standard deviation (SD) for continuous variables, frequencies (percentage) for categorical variables. Results thus obtained were subjected to statistical analysis. $p<0.05$ was considered statistically significant. Data were statistically evaluated with IBM SPSS Statistics for Windows version 20.0 .

\section{RESULTS}

A total of 400 children were included in our study. Fig. 1 shows the overall prevalence of anemia among the study population and Fig. 2 shows the percentage distribution of gradation of anemia as per severity among the age group between 6 months and 5 years. Table 1 shows the comparison between anemic and non-anemic children. Significantly higher number of anemic children were found to be overweight or obese and vegetarian.

\section{DISCUSSION}

The current study revealed that the prevalence of nutritional anemia among children of high socioeconomic group was $44.5 \%$. The prevalence of anemia in Tamil Nadu according to NFHS-4 was $50.4 \%$ of which the prevalence in urban areas was around $48.2 \%$ [6]. This indicates that nutritional anemia is a public health problem among all socioeconomic groups, as according to the WHO, if prevalence is more than $40 \%$, it is considered to be a severe problem of concern [4]. Our study further showed that the prevalence of anemia decreases with increasing age. One of the

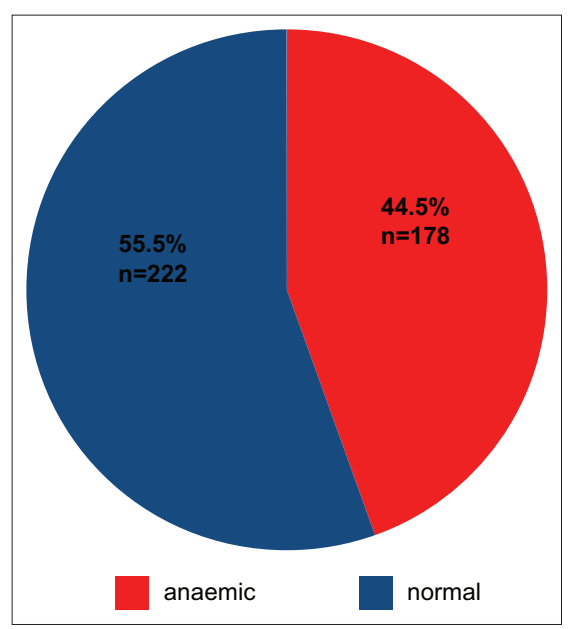

Figure 1: Prevalence of anemia among the study population $(n=400)$

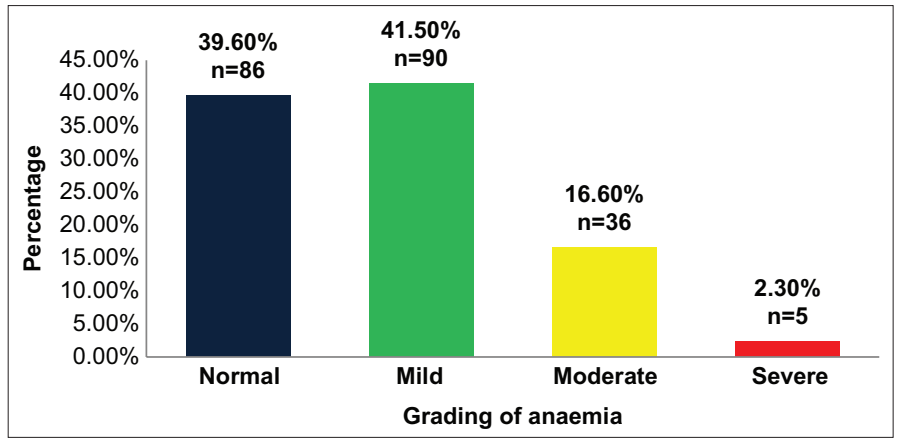

Figure 2: Grading of anemia among study participants aged between 6 months and 5 years $(n=217)$

studies done in Malaysia showed that the prevalence of anemia was higher in young children as compared to school-going children [16]. The present study showed a significant association between prevalence of anemia and age of the children $(\mathrm{p}<0.001)$.

We found that within 6-59 months age group, majority had mild anemia followed by moderate and severe anemia. Similar study by Bharti et al. based on NFHS-4 (2015-2016) showed that the prevalence of anemia was 56\% among 6-59 months old children in India [17]. Reports from NFHS-5 (2019) show that the prevalence of anemia among children (6-59 months) in neighboring states ranges from $39.4 \%$ in Kerala to $65.5 \%$ in Karnataka [18].

In a study carried out based on Bangladesh Demographic and Health survey, Khan et al. showed that the prevalence of anemia among 6-23 months old children was $28 \%$ greater than in 24-59 months old children [19]. Studies show that iron deficiency if uncorrected before 24 months age might result in cognitive impairment in those children $[11,12]$. There were a significantly higher number of overweight and obese children among those anemic in all age groups. A study by Sypes et al. showed that children with a higher body mass index had an increased risk for iron deficiency [20].

Although the present study was not designed to evaluate all the risk factors for nutritional anemia, we found that age, gender, and dietary pattern were the variables that had a significant association with anemia. It showed that children 
Table 1: Association of demographic variables with anemic status

\begin{tabular}{|c|c|c|c|}
\hline Variable & $\begin{array}{c}\text { Anemia } \\
\text { present }(n=178) \\
\text { frequency }(\%)\end{array}$ & $\begin{array}{c}\text { Anemia } \\
\text { absent }(n=222) \\
\text { frequency }(\%)\end{array}$ & $\begin{array}{l}\text { Chi-square } \\
\text { (df) } P \text { value }\end{array}$ \\
\hline \multicolumn{4}{|l|}{ Age group } \\
\hline 6 months -5 years & $139(78.1)$ & $98(44.1)$ & $48.636(2)$ \\
\hline 5-11 years & $36(20.2)$ & $103(46.4)$ & \\
\hline $12-14$ years & $3(1.7)$ & $21(9.5)$ & $<0.001$ \\
\hline \multicolumn{4}{|l|}{ Socioeconomic class } \\
\hline Upper & $91(51.1)$ & $130(58.6)$ & $2.209(1)$ \\
\hline Upper middle & 87 (48.9) & $92(41.4)$ & 0.137 \\
\hline \multicolumn{4}{|l|}{ Peripheral smear } \\
\hline $\begin{array}{l}\text { Dimorphic } \\
\text { smear }\end{array}$ & $2(1.2)$ & $0(0)$ & $532.003(2)$ \\
\hline $\begin{array}{l}\text { Microcytic } \\
\text { hypochromic } \\
\text { anisocytosis }\end{array}$ & $176(98.8)$ & $4(1.8)$ & $<0.001$ \\
\hline $\begin{array}{l}\text { Normocytic } \\
\text { normochromic }\end{array}$ & $0(0)$ & $218(98.2)$ & \\
\hline \multicolumn{4}{|l|}{ Centile } \\
\hline Obese & $15(8.4)$ & $8(3.6)$ & $24.974(3)$ \\
\hline Overweight & $21(11.8)$ & $15(6.8)$ & \\
\hline Normal & $118(66.3)$ & $191(86.0)$ & $<0.001$ \\
\hline $\begin{array}{l}\text { Thinness/ } \\
\text { malnourished }\end{array}$ & $24(13.5)$ & $8(3.6)$ & \\
\hline \multicolumn{4}{|l|}{ Diet } \\
\hline Vegetarian & $126(70.8)$ & $113(50.9)$ & $16.244(1)$ \\
\hline Non-vegetarian & $52(29.2)$ & $109(49.1)$ & $<0.001$ \\
\hline
\end{tabular}

$\mathrm{N}$ : Total number of patients, df: Degrees of freedom

with normal nutritional status also have some degree of nutritional anemia.

\section{CONCLUSION}

This study shows that prevalence of nutritional anemia among children of high socioeconomic status is a problem of high magnitude, and the prevalence decreases with increasing age. It also shows that females and vegetarians have a higher risk of iron deficiency anemia. Children of 6-23 months have a higher prevalence of iron deficiency anemia which if left uncorrected might lead to irreversible cognitive impairment, thereby emphasizing the need to screen and supplement iron to all children under-5 years irrespective of socioeconomic status. Large-scale studies among community are necessary to better understand the nutritional iron status of children. To keep the "next-generation" healthy, the iron supplements for all should be the motto.

\section{REFERENCES}

1. Chaparro CM, Suchdev PS. Anemia epidemiology, pathophysiology, and etiology in low-and middle-income countries. Ann N Y Acad Sci

\section{9;1450:15.}

2. World Health Organisation. Guideline: Daily Iron Supplementation in Infants and Children. Geneva: World Health Organisation; 2016. Available from: https://www.apps.who.int/iris/bitstream/ handle/10665/204712/9789241549523_eng.pdf. [Last accessed on 2021 Sep 09].

3. Kassebaum NJ, Jasrasaria R, Naghavi M, Wulf SK, Johns N, Lozano R, et al. A systematic analysis of global anaemia burden from 1990 to 2010 . Blood 2014;123:615-24.

4. World Health Organization. The Global Prevalence of Anaemia in 2011. Geneva: World Health Organization; 2015. Available from: https://www. apps.who.int/iris/bitstream/handle/10665/177094/9789241564960_eng.pdf. [Last accessed on 2021 Sep 09].

5. International Institute for Population Sciences, ORC Macro. National Family Health Survey (NFHS-3), 2005-06. Vol. 1. Mumbai, India: International Institute for Population Sciences; 2007.

6. International Institute for Population Sciences, ORC Macro. National Family Health Survey (NFHS-4), 2015-16. International Institute for Population Sciences; 2009

7. Dallman PR, Yip R, Johnson C. Prevalence and causes of anemia in the United States, 1976 to 1980. Am J Clin Nutr 1984;39:437-45.

8. Kyu HH, Pinho C, Wagner JA, Brown JC, Bertozzi-Villa A, Charlson FJ, et al. Global and national burden of diseases and injuries among children and adolescents between 1990 and 2013: Findings from the global burden of disease 2013 study. JAMA Pediatr 2016;170:267-87.

9. McLean E, Cogswell M, Egli I, Wojdyla D, De Benoist B. Worldwide prevalence of anaemia, WHO vitamin and mineral nutrition information system, 1993-2005. Public Health Nutr 2009;12:444-54.

10. Subramaniam G, Girish M. Iron deficiency anaemia in children. Indian J Pediatr 2015;82:558-64.

11. Kotecha PV. Nutritional anaemia in young children with focus on Asia and India. Indian J Community Med 2011;36:8.

12. Miller JL. Iron deficiency anemia: A common and curable disease. Cold Spring Harbor Perspect Med 2013;3:a011866.

13. Hutchinson C. A review of iron studies in overweight and obese children and adolescents: A double burden in the young? Eur J Nutr 2016;55:2179-97.

14. Nemeth E, Ganz T. The role of hepcidin in iron metabolism. Acta Haematol 2009;122:78-86.

15. Sharma, R. Revised Kuppuswamy's socioeconomic status scale: Explained and updated. Indian Pediatr 2017;54:867-70.

16. Ngui R, Lim YA, Kin LC, Chuen CS, Jaffar S. Association between anaemia, iron deficiency anaemia, neglected parasitic infections and socioeconomic factors in rural children of West Malaysia. PLoS Negl Trop Dis 2012;6:e1550.

17. Bharati S, Pal M, Bharati P. Prevalence of anaemia among 6-to 59-monthold children in India: The latest picture through the NFHS-4. J Biosoc Sci 2020;52:97-107.

18. National Family 2019-20 Health Survey (NFHS-5), Fact Sheets. Available from: http://www.rchiips.org/NFHS/NFHS-5_FCTS/NFHS-5\%20State $\% 20$ Factsheet\%20Compendium_Phase-I.pdf. [Last accessed on 2021 Sep 07].

19. Khan JR, Awan N, Misu F. Determinants of anaemia among 6-59 months aged children in Bangladesh: Evidence from nationally representative data. BMC Pediatr 2016;16:3.

20. Sypes EE, Parkin PC, Birken CS, Carsley S, MacArthur C, Maguire JL, et al. Higher body mass index is associated with iron deficiency in children 1 to 3 years of age. J Pediatr 2019;207:198-204.

Funding: None; Conflicts of Interest: None Stated.

How to cite this article: Kalaiselvam $\mathrm{P}$, Chelliah S, Pachamuthu M. Prevalence of nutritional anemia in children of high socioeconomic status in a tertiary care center. Indian J Child Health. 2021; $8(10): 359-361$ 